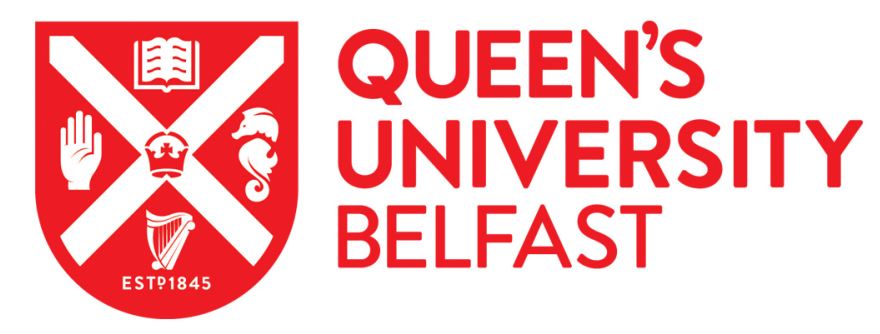

\title{
Who's picking up the bill?
}

McKenna, G., Allen, F., Schimmel, M., \& Müller, F. (2015). Who's picking up the bill? Gerodontology, 32(3), 161162. https://doi.org/10.1111/ger.12205

\section{Published in: \\ Gerodontology}

\section{Document Version:}

Peer reviewed version

\section{Queen's University Belfast - Research Portal:}

Link to publication record in Queen's University Belfast Research Portal

\section{Publisher rights}

(C) 2015 John Wiley \& Sons

This is the peer reviewed version of the following article: McKenna, G., Allen, F., Schimmel, M. and Müller, F. (2015), Who's picking up the bill?. Gerodontology, 32: 161-162., which has been published in final form at http://onlinelibrary.wiley.com/doi/10.1111/ger.12205/abstract. This article may be used for non-commercial purposes in accordance with Wiley Terms and Conditions for Self-Archiving.

\section{General rights}

Copyright for the publications made accessible via the Queen's University Belfast Research Portal is retained by the author(s) and / or other copyright owners and it is a condition of accessing these publications that users recognise and abide by the legal requirements associated with these rights.

\section{Take down policy}

The Research Portal is Queen's institutional repository that provides access to Queen's research output. Every effort has been made to ensure that content in the Research Portal does not infringe any person's rights, or applicable UK laws. If you discover content in the Research Portal that you believe breaches copyright or violates any law, please contact openaccess@qub.ac.uk. 


\section{Who's picking up the bill?}

Interventions for oral care have significant health relevance with oral disease affecting an estimated 3.9 billion people worldwide. Daily adjusted life years (DALYs), a marker of the burden of oral disease, are estimated to have globally risen by $20 \%$ in the past 20 years as a consequence of population growth, demographic transition and changing dental disease patterns ${ }^{1}$. The costs of care delivery and maintenance continue to increase dramatically which in turn can have negative impacts on access to oral healthcare for older patients ${ }^{2}$. Current estimates indicate that treatment of oral disease accounts for $5 \%$ of public health spending across the European Union with annual treatment costs rising from $€ 54$ billion in 2000 to a projected $€ 93$ billion in 2020 , a cost greater than the management of stroke and dementia combined. In their current form, global health systems are ill-prepared to cope with the escalating burden of care and its associated costs. There is evidence of inequality of access to oral healthcare services for many older people, with those over the age of 50 years experiencing income related barriers to preventive oral healthcare ${ }^{3}$. Accordingly, the financial cost of tooth loss disproportionately affects older age groups. There is a need for elderly patients, therefore, to achieve better clinical outcomes, which are also costeffective. Unfortunately, to date very little health economics research has been targeted specifically towards dentistry ${ }^{4}$.

Natural teeth in the older population will be difficult and costly to manage despite benefits to food choice, quality of life and general health. ${ }^{3}$ Frequently the treatment choices for older people who have lost teeth are confusing. Removable partial dentures (RPDs) can be expensive to make and difficult to maintain, and many are not used ${ }^{5}$. Implant retained prostheses are another approach to tooth loss, but they are very expensive and beyond the means of most publically funded healthcare programs, ${ }^{6}$ and surgery frightens many people ${ }^{7}$. Replacement of all missing teeth may not be desired by or appropriate for everyone. Recently, treatment concepts have become functionally oriented to accept a reduced but healthy natural dentition based on a minimally invasive management of caries, and avoiding dentures ${ }^{8}$. From a public health viewpoint functionally oriented dentistry is particularly relevant to patients at moderate to high risk of caries and periodontal disease, and especially when access to treatment is difficult ${ }^{9}$.

Currently there is lack of coherence in policy making and evidence based guidelines for preventing oral diseases in older people. ${ }^{10} \mathrm{We}$ need equitable third party insurance schemes for oral healthcare in order to bridge the funding deficit in public funding ${ }^{11}$. Ideally, this should be based on effective, prevention-based oral healthcare in primary care settings which are easily accessible to all older patients. Global policy making for the older patient must integrate oral examinations with health screening programmes, and increase training of ancillary healthcare professionals to provide elements of preventive care to patients in a more affordable way ${ }^{12}$. In addition, remuneration systems should promote minimally invasive rather than complicated surgical and restorative treatments.

\section{References}


1. Marcenes W, Kassebaum NJ, Bernabe E et al. Global burden of oral conditions in 1990-2010: a systematic analysis. J Dent Res 2013; 92: 592-597

2. Meija G, Jamieson LM, Ha D et al. Greater inequalities in dental treatment than in disease experience. J Dent Res 2014; 93: 966-971

3. Listl S. Income-related inequalities in dental service utilization by Europeans aged 50+. J Dent Res 2011; 90: 717-723

4. Shariati B, MacEntee MI, Yazdizadeh M. The Economics of dentistry: A neglected concern. Community Dent Oral Epidemiol 2013; 41: 385-394.

5. Xie Q, Ding T, Yang G. Rehabilitation of oral function with removable dentures - still an option?

6. MacEntee MI, Walton JN. The economics of complete dentures and implant-related services: a framework for analysis and preliminary outcomes. J Prosthet Dent 1998; 79:24-30

7. Walton JN, MacEntee MI. Choosing or refusing oral implants: A prospective study of edentulous volunteers for a clinical trial. Int J Prosthodont 2005; 18:483-8.

8. McKenna G, Allen PF, O'Mahony D et al. The impact of rehabilitation using removable partial dentures and functionally orientated treatment on oral healthrelated quality of life: a randomised controlled clinical trial. J Dent 2015; 43: 66-71

9. McKenna $\mathrm{G}$, Allen PF, Woods $\mathrm{N}$ et al. Cost-effectiveness of tooth replacement strategies for partially dentate elderly: a randomised controlled clinical trial. Comm Dent Oral Epidemiol 2014; 42: 366-374

10. Petersen PE, Kandelman D, Arpin S et al. Global oral health of older people - a call for public health action. Community Dent Health 2010; 27: 257-267

11. Yao CS, MacEntee M. Inequity in Oral Health Care for Elderly Canadians: Part 3. Reducing Barriers to Oral Care. J Can Dent Assoc 2014; 80; e11

12. Calache $\mathrm{H}$, Hopcraft MS. Provision of oral healthcare to adult patients by dental therapists without the prescription of a dentist. J Public Health Dent 2012; 72: 19-27

Gerry McKenna,

Senior Lecturer and Consultant in Restorative Dentistry,

Centre for Public Health, Queens University Belfast

P Finbarr Allen,

Professor of Prosthodontics and Oral Rehabilitation,

University College Cork

Martin Schimmel,

Professor of Gerodontology and Removable Prosthodontics,

University of Bern

Frauke Müller,

Professor of Gerodontology and Removable Prosthodontics,

University of Geneva 